there were no appearances, either in the brain or its membranes, to account for the severe functional disturbance of the nervons centres which not unfrequently occurred. In some instances, even where the poison appeared to have been very intense, the brain remained perfectly unaffected througbout.

The constitutional disturbance presented every degree of intensity, being in some cases very severe from the onset; while in others it was so slight, and there was so little vital prostration, that but for the enteric symptoms it would scarcely have been necessary to keep the patients to their beds.

In about six cases there were fallacious apjearances of recovery, lasting for a few days, and followed by a distinct relapse.

On post-mortem examination of the fatal csses, there was always found more or less serious lesion of Yeyer's patches and of the solitary glands of the lower part of theileum. In Case 3 , where death took place at the end of the first week from the commencement of the attack, there was merely an enlarged and inflamed state of Peyer's patches, and inflammation of the adjacent mucous membrane. In Case 4 , where the disease had made somewhat more progress, Peyer's and the solitary glands were prominent and congested, and some of them superticially ulcerated; there was also great congestion of the mucous membrane of the end of the ileum. In Case 7, some of Peyer's patches were prominent, and capped with greyish matter; while others, nearer to the termination of the ileum, were more or less ulcerated. In another case, elliptical ulcers occupied the place of the patches, and the adjacent peritoneum was implicated in the inflammatory action. In all the cases, the mesenteric glands corresponding to the inflamed intestine were in a greater or less degree enlarged, congested, and succulent. In Case 7, both the liver and spleen were considerably enlarged, the former of deep venous colour, and both very soft and friable. A congested state of the bronchial mucous membrane was very frequently met with, and, less frequently, serous engorgement of one or both lungs. In only one case was there found any alteration of the brain or its membranes, and then it consisted ouly in slight congestion.

(To be concluded.)

\section{PRESERVATION OF ANIMAL AND VEGETABLE ALIMENTS.}

MODE OF PROCURING AN ECONOMICAL AND ABUNDANT SUPPLY OF FHESH ANIMAL FOOD.

By R. M. GLOVER, M.D., F.R.S.E., ETC.

FEw subjects are worthy of more attention than that which stands at the head of this short paper. It is one of the most important that can be conceived, and involves neither more nor less than the economical subsistence of the mass of the people, and the provisioning of fleets and armies. Its importance appears to have been deeply felt by Lord Bacon, "who lost his life in experimenting on the power of cold to preserve animal food. It is obvious that as there are lands where animal food is in superabundant quantity in proportion to the population, if it can be preserved fresh in a cheap and ready mode, and exported to countries where the reverse is the case, great benefit will accrue to all the parties concerned,-both to the inhabitants of the more densely-populated countries and of those containing excess of animal food; for the latter will obtain a market for their surplus produce, which is now in many instances wasted, and their agricultural resources be greatly developed. Even in countries like England and France it is often of consequence to preserve meat from spoiling, without having recourse to the salting process. It is needless to say that all this has occurred to many, and that several plaus have been from time to time devised. At length this great problem seems on the eve of a satisfactory solution. As far as the mere fact of preservation is concerned there is no difficulty at all; the object to be attained is to preserve the aliment, and especially animal food, in its fresh state, as nearly as possible as when killed, and above all with a due regard to economy.

The methods of preserving both animal and vesetable tood are very various: by drying or freezing, by exclusion of air, and by the use of various chemical means, - as by what are

* "It is an inquiry of excellent nse to inquire of the means of preventing or staying of putrefaction." $-N a t$. IIst., cent. iv. termed antisentic agents. Most of these act by combining chemically with the tissues, and forming new compounds incapable of putrefaction. Such are especially, corrosive sublimate, most of the acids, creosote, alcohol, salts - as common salts. Others are of a more doubtful kind of action-as perhaps sugar, charcoal, sulphur. Most of the chemical antiseptics are more or less apt to cause meat preserved by them to have an injurious effect on the constitutions of those who partake of them, as is shown by the effect of the long-continued use of salted meat. The power of charcoal and the various forms of carbon to arrest putrefaction does not seem to be chemical, and the same is probably the case with sulphur; but in what manner these substances are antagonistic of the putrefactive principle is not clearly made out. The nature of the compounds which such substances as common salt form with the albuminons tissues is not known, for all the so-called protein compounds with acids and salts can now hardly be admitted as real. That common salt does change the constitution of meat seems evident by the hardness of fibre induced by salting. In corrosive sublimate, this action is shown in an intense degree.* Oils and syrups, especially the former, probably preserve by excluding air.

Many modes of preserving meats are in nse amongst rude peoples, which are always capable of some more general application. For instance, the inhabitants of many hot countries dry their meat quickly by means of the heat of the sun, like the buccaneers of former times. The Mongols and Tartars dry it and rednce it to powder. The practice of smoking meat is pretty general. Here the empyreumatic oils of the wood are the chief agents, although various gases disengaged assist Pemmican is a preparation of deer's flesh, much used by the Hudson Bay Company's hunters, and arctic voyagers, preserved with the aid of the fat, mnch like our preserved meat and game. A mode of preserving by imbedding the powdered meat, well spiced, in fat is pursued in the East. That method of using prepared membranes of the intestines of oxen, as in the Bologna and German sausages, to include spiced and smoked meats, is of the same class. But these methods are all exceptional.

Recently three papers by MM. Chevallier, father and son, have been published in the Annales de Hygiene for July and October, 1857, and January of the present year, which give the best account of the present state of the question extant. In 1813, the French Society of Fncouragement, proposed a prize of 2000 francs for a good method of preserving animal food. At that time meat dried by a M. Villaris, ten years before, was in existence, which still afforded a good soup. The author of the invention was dead, and his process remained secret. The successful candidate was M. Appert, who, in 1824, received the prize. His method consisting in enclosing the meat, carefully dried, in air-tight cases, from which the air had been expelled by the heat of boiling water, and then the small orifice left in the case hermetically sealed. In 1824, Captain Parry left in the Arctic regions some cases of preserved meat, prepared by Messrs. Gamble and Donkin on the principle of removal of air, which were brought home by Captain Koss, eleven yeurs after. They presented severa! bulgings produced $\mathrm{ky}$ atmospheric pressure. The meat was quite good.

The method of preserving meat in air-tight cases, from which the air has been removed, has been generally employed with success. Its great drawback is, that it is hardly applicable on the large scale contemplated for extensive industrial purposes.

Several parties have pointed out the uses of pyroligneous acid as a preservative. Considerable quantities of fish-tunny, for instance-are thus preserved in jars, on the Mediterranean coast, but the flesh is hard. Sardines and other small fish are preserved in oil. Dried animal substances, by surrounding them with gluten or gum. Chorcoal, ivory-black, and soot have been proposed. Dried meat, wrapped in paper whose surface is covered with a mixture of charcoal-powder and gum arabic, keeps quite well, especially if packed in boxes of char-

* The precise nature of the compound which corrosive sublimate forms with albumen is, I think, still unknown. It has been contended that the corrosive sublimate is reduced to the state of calomel, which was Orfila's view, and have elsewhere reasoned against it. According to Lassaigne, the corrosive sublimate is combined as such. A striking proof of the misapplication of chemical views to physiology is affurded by Iiebig's explanation of the supposed more energetic action of arsenic as a poison over corrosive sublinate, in the larger proportional equivalent of tibrin which the former can combine with; the fact being that arsenic is hardly a corrosive poison: it is an irritant. Every corrosive poison is irritant, because it inflicts a physical injury on the tissues; but every irritant is not a corrosive, the action being often parely
vital. 
coal powder. This reat, however, is found rather solid when used.

A host of different modes of drying meat have been pro posed. After a method, for example, somewhat similar to the mode of drying organic matters for analysis; as by pass. ing air first over quick lime, or chloride of calcium, then through a heated chamber or tubes, and then through a reservoir containing the substance to be dried, which might then be wrapped in a cement of plaster of Paris and charcoal, made up with solution of alum, and the whole enclosed in tinfoil.

The vapours of carbonic acid and peroxide of azote have preservative properties, and may $b ə$ employed to expel oxygen from the substance to be preserved in a reservoir. Most of the anæsthetic agents, especially chloroform and the Dutch liquid, are antiseptic, and their vapours have similar properties, but of all the gaseous bodies, none have had such good results as sulphurous acid gais. The following is the process of $M$. Robert:-After death, insufflation should be practised, and the parts to be preserved freed as much as possible from blood and serosity, then dried in a current of air produced by a ventilator, then suspended in a close chamber, and exposed to a current of sulphurous acid gas for a period of from ten to twenty-five ninutes, according as the weight of the ment to be preserved varies from two to one hundred kilogrammes; then exposed to the air, and covered with a layer of some impervious substance; after which it may be packed in barrels. (1855).

Fatio and Verdeil proposed (1Sō5) to cook in a current of steam under a pressure of from four to five atmospheres, and then dry.

It has been proposed to inclose the dried substance in a case, produce a vacuum by the heat of the salt-water bath, the apparatus being so constructed that by opening a stopcock the preservative substance-melted fat, for instance-might enter.

Of all these methods, MM. Chevallier give the preference to the use of sulphurous acid. The conservative powers of this gas, and the solution of the acid, have been often tested. Fntire sheep killed at Algiers, and cleaned there, have been exposed to a current of this gas, brought to Paris, and found at the end of a month in such a state that they might be sold in any butcher's shop in the capital. Meat so treated in France, in the hot weather of August last, was found quite good at the end of a month.

The preservation of veretables may be conducted on the same principles as that of animal substances, but in general the former require less pains. Quantities of compressed vegetables, forming part of the stores brought from the East, are now to be purchised in the grocers' shops of the metropolis.

Of course there is another way of utilizing the excessive abundance of animal food in some countries--viz., by preparing an extract of meat according to the principles lajd down by Liebig. Dr. Daubeny, in his address to the British Association, at Cheltenham, 1856, says: "Chemistry has shown how our supply of animal food may be obtained at a cheaper rate from the antipodes by simply boiling down the flesh of cattle now wasted and thrown aside in these countries, and importing the extract in a state of concentration." In THE LANCET of August 26th, 1854, will be found a letter from me on the "Provisioning of Armies," in which I urge the importance of sending ont a large supply of this preparation to the East, pointing out the great advantages which its facility of transpor afforded. Afterwards, I had often to prescribe it myself, as we had plenty of it at Sentari, towards the close of the war. The soup prepared from it was certainly not so good as from fresh meat, but it was still excellent, a most valuable resource to the medical man, and an agreeable relief to the patient.

One great drawback to the realizing of the enormous alimentary resources of such conntries as Buenos Ayres, the Cape, and Australia-viz., the scarcity of fuel, is removed by the use of sulphurous acid as the preserving agent. For the combustion of the sulphur once excited is easily maintained, and the article itself is cheap enough.

The utility of preserving the flesh of sheep fresh is even greater than in the case of cattle, on account of the difficulty with which the former takes salt, and the great abundance of Alocks in mary places far exceeding that of cattle. Admitting that much of this mutton may be inferior to prime English meat, it may still be an immense boon to the worining classes.

But, moreover, the establishments in these countries at which food was so prepared could also be turned into account in producing useful materials from other parts of the animals, of which only the horns, hides, and tallow are now useful, artificial manures, for instance, and varions chemical compounds, which need not be enumerated here. Patents have been taken out in this country for the application of sulphurous acid in various ways.

I have not thought proper to allude to all the processes for preserving food, but merely to the more important. M. Gannal proposed to inject the veins of recently killed animals with chloride of aluminum - in fact his embalming process, but this, only a modification of salting, is clearly inadmissible.

In conclusion, I conceive that the preservation of animal food, so as to convey it fresh from distant countries is a question of national importance not inferior to any other, and well worthy the attention of government. It seems to me not of an inferior rank to the repeal of the corn laws. But it is a subject for the investigation of scientific men, and as such we can hardly expect it to be taken up amid the contentions and turmoils of party war.

Mareh, 1858.

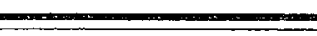

\section{OIV A CASE OF}

\section{TETANIC CONVULSIONS, SIMULATING} POISONING BY STRYCHNIA.

\section{BY JOHN ROBERTS, M.D.,}

PHYSICIAN TO THE SALISBURY INTRMABY.

RichaRd $\mathrm{T} \longrightarrow$, aged twenty-eight, a gardener, was admitted into the Salisbury Infirmary at noon on Feb. 17th. He was a dark, sallow, and feeble-looking man, and appeared to be much older than he really was. He stated that, although not strong, he had always enjoyed good health, and that he never required medical attendance except once, about four years ago, when he was attacked with great pains in the abdomen, apparently of an inflammatory character, for which he was freely leeched and cupped, the marks of the treatment being plainly visible. For several months past he had been travelling about the country in search of employment, and two days before admission he had travelled from Bangor, in North Wales, to Bath. On the following morning he started for his mother's house at Southampton, reaching Salisbury at seven o'clock in the erening, having walked the last twenty miles of the journey. Being distressed for money, he had sold his only pair of stockings; and, as the weather at the time was very cold, he keenly felt the want of them, for his legs by the time he reached his lodgings, felt benumbed. Having partaken of some tea and bread-and-butter, he went to bed, but continued to feel cold and chilly. After he had been some time asleep, he was attacked with a slight diarrhoea, griping, and sickness, which, however, soon passed off. Though not feeling well, he rose before seven o'clock, and attended the early morning service at the cathedral; after which he returned to his lodg. ings, and had his breakfast, which consisted of tea, bread, and a small piece of fish. Althongh feeling rather weak, he was comparatively well until about twelve o'clock, when he was suddenly attacked by a fearful and strange disease, which I (as well as every body else who saw him) expected every moment to prove fatal.

Symptoms on admission during a paroxysm. - His eyes were starting out and prominent, with a glare and wildly anxious look; the nostril spread, mouth widely open, and all his features fixed and ghastly. He was flinging his arms riolently about him, gasping for breath, and bis whole body was convulsed. There was a general contraction of all the muscles, but those of the neck and back were most severely affected. The pressure upon the respiratory muscles was enormous, and the sense of strangulation terrible in its intensity. His face was congested and livid, and the pressure upon the veins of the neck was so great that they stood out and looked as large as a good-sized walking-stick. When the paroxysm was coming on be uttered loud shrieks, and beat with his arms the bed and his chest with great violence; there was frightful laryngismus, vain efforts at expiration, and complete opisthotonos of the neck and back; the extremities also were stiffened and jerked out. During the whole of this time he was perfectly conscious. When the paroxysm was over, there was no stiffness of the jaw or neck; he was able to swallow, and frequently called for drink; he breathed easily, and was free from all suffering. The convulsions invariably commenced with a digging pain at the pit of the stomach; soon after the abdominal muscles became contracted and rigirl as a warped board. At this stage he always earnestly asked to be rubbed, and when the feeling of straygulation came on his cries and prayers for relief were 